\title{
Dynamic Viscoelasticity of Aqueous Disperse Systems of Carboxymethylcellulose
}

\author{
by \\ Kimio MASHIKo*1 and Takayoshi Matsumoto*2 \\ *1 Japan Tabacco Incorporated, Hiratsuka Research Institute of Engineering, \\ 1-31 Kurobeoka, Hiratsuka, Kanagawa 254 \\ and \\ *2 Department of Polymer Chemistry, Kyoto University, \\ Kyoto 606
}

\begin{abstract}
Weight average molecular weight $\left(M_{\mathrm{w}}\right)$ of sodium carboxymethylcellulose $(\mathrm{NaCMC})$ has been determined by the light scattering in the solution of triethylenediamine cadmium hydroxide (cadoxene). The relation between $M_{\mathrm{w}}$ and the limiting viscosity number $[\eta]$ in $0.1 \mathrm{~N} \mathrm{NaCl}$ aqueous solution has been obtained and it has been found that the Staudinger's relationship $[\eta]=K M_{\mathrm{w}}$ can be applied for these systems.

Dynamic viscoelastic properties of aqueous disperse systems of NaCMC have been measured by means of a cone-and-plate type rheometer. Using three series of NaCMC in the range of substitution (carboxymethyl residue/glucose unit) 0.5 to 1 with various degree of polymerization, the effects of the degree of substitution $(D S)$, the degree of polymerization and the concentration upon rheological properties have been investigated. The influence of $D S$ is marked in the long time-scale region. NaCMC of low DS remarkably shows a second plateau which is a characteristic property of the heterogeneous system. On the other hand, NaCMC of high DS behaves like homogeneous polymeric liquid.
\end{abstract}

\section{カルボキシメチルセルロースー水分散系の動的粘弾性}

\author{
益子公 男*・松 本 孝 芳**
}

（原稿受理：1986年 3 月 5 日）

\section{1. 緒言}

天然多糖類及びその誘導体は, 食品, 製紙及び纎維工業をはじ め多くの分野で, 増粘剤, 接着剂, 分散安定剂等として利用され ている. 特に, セルロース誘導体であるカルボキシメチルセルロ 一スのナトリウム塩 ( $\mathrm{NaCMC}$ ) は, 品質の均一安定性, 多様性 及び価格等の点から利用度は高く, 工業的に重要な役割を果たし ている.

しかし， $\mathrm{NaCMC}$ の工業的利用に当たって，そのレオロジー的 特性の把握は必要, かつ重要であるにもかかわらず, カルボキシ メチル基の置換度 (エーテル化度), 重合度及び濃度等を広範囲 に系統的に変えて行った研究例は少ない. このため, 利用目的に

*日本たばこ産業株式会社平塚生産技術研究所 $\bar{T} 254$ 神奈川県平塚 市黒部丘 $1-31$

** 京都大学工学部高分子化学教室 $\quad$ T606 京都市左京区吉田本町
応じた処方, 調整法は, 勘に頼る部分が多かったものと考えられ る.

これらの理由の一つとして, $\mathrm{NaCMC}$ の高分子電解質としての 複雑性を挙げるととができる，すなわち， $\mathrm{NaCMC}$ の水中におけ る電離の程度が分散濃度や塩の存在等, 条件によって複雑に変化 するばかりでなく，エーテル化度に大きく支配されているため， これらの因子とレオロジー特性の関連づけが困難であった.

一方, 希薄溶液の粘度測定については, いくつか報告例はみら れるが(1) 7), その重要な因子である電離基密度，すなわちエーテ ル化度, 及び重合度を考慮した系統的な測定例は殆どみられな (2) 10 ).

ここでは, $\mathrm{NaCMC}$ 希薄溶液の極限粘度の測定も含め, 工業的 利用に当たって重要である濃厚水分散系の動的粘弾性に及ぼすエ ーテル化度, 重合度及び濃度の影響について報告する。 


\section{2. 試料及び実験}

\section{$2 \cdot 1$ 試 料}

用いた試料は, 単一種のパルプから溶媒法により作成した種々 の重合度及びェーテル化度の $\mathrm{NaCMC}$ である。乙れらは第一工業 製薬侏より供試を受けた。供試試料は $80 \%$ エタノールー水溶液で 24時間抽出, 沪過, 洗浄を二度くり返した後, 室温で 5 日間真空 乾燥した.

後述する方法により測定した $\mathrm{NaCMC}$ のエーテル化度 $D S$, 重 量平均分子量 $M_{\mathrm{w}}$, 重量平均重合度 $P_{\mathrm{w}}$, 及び数平均重合度 $P_{\mathrm{n}}$ を表厂に示す.

レオロジー測定に用いた $\mathrm{NaCMC}$ 水分散系は, $\mathrm{NaCMC}$ 之所定 量の蒸留水を混合した後, 充分吸水膨潤させ, 混練をくり返し, さらに密閉容器で 7 日間安定化した後, 測定に供した.

\section{$2 \cdot 1 \cdot 1$ エーテル化度}

エーテル化度は，灰化滴定法によって測定した ${ }^{11)}$.

エーテル化度 $D S=1.0$ の場合の $\mathrm{NaCMC}$ の化学式を下に示す.

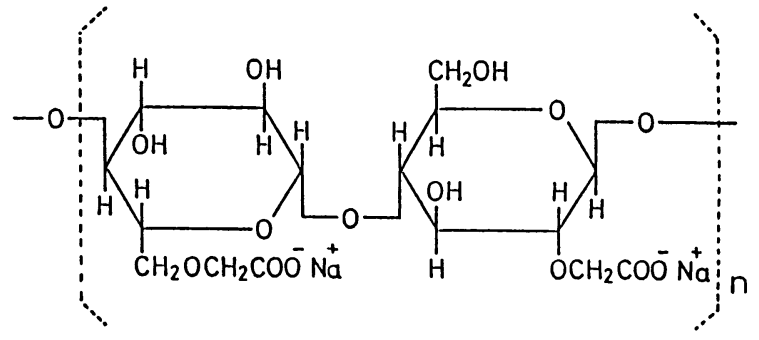

エーテル化度は, 無水グルコース単位当たりの置換体（カルボ キシメチル基）と反応した水酸基の平均数值であり，最大 3 であ る.

エーテル化度の分布が分散系のレオロジー特性に大きく影響す るという定性的な報告もあるが99,12)，分布の測定は困難であるた め, ここでは平均値で表示した。

\section{$2 \cdot 1 \cdot 2$ 重量平均分子量及び重合度}

重量平均分子量 $\left(M_{\mathrm{w}}\right)$ は, $\mathrm{NaCMC}$ のカドキセン (trimethy. lenediamine cadmium hydroxide) 溶液について, 低角度レーザ 一光散乱光度計 (Chromatix 社製, KMX 6) を用い，散乱角6〜

Table I. Code of NaCMC, degree of substitution, molecular weight, degree of polymerization and specific refractive index increment.

\begin{tabular}{lcccll}
\hline Sample & $D S$ & $M_{\mathrm{w}} \cdot 10^{-5}$ & $P_{\mathrm{w}}$ & \multicolumn{1}{c}{$P_{\mathrm{n}}$} & $\mathrm{d} n / \mathrm{d} c(\mathrm{ml} / \mathrm{g})$ \\
\hline CM1 & 0.50 & - & - & $200 \pm 30$ & \\
CM13 & 0.51 & 1.87 & 922 & 437 & 0.150 \\
CM25 & 0.57 & 2.51 & 1209 & $750 \pm 50$ & $0.146^{*}$ \\
CM4 & 0.91 & 1.45 & 618 & 178 & $0.126^{*}$ \\
CM16 & 0.88 & 2.06 & 886 & 301 & 0.128 \\
CM15 & 0.80 & 2.15 & 951 & 349 & $0.133^{*}$ \\
CM34 & 0.92 & 7.90 & 3357 & 956 & $0.126^{*}$ \\
CM18 & 1.13 & 2.22 & 880 & 314 & 0.110 \\
CM36 & 1.31 & 5.85 & 2193 & 1569 & 0.110 \\
\hline
\end{tabular}

* Interpolated from the plot of $\mathrm{d} n / \mathrm{d} c$ and $D S$.
$7 \mathrm{deg}$ で測定した. NaCMC-カドキセン溶液 ${ }^{13)}$ の $\mathrm{d} n / \mathrm{d} c$ は, 示 差屈折率計 (UNION 社製, RM-101) を用いて測定した. こて で, $n$ は溶液の屈折率, $c$ は $\mathrm{NaCMC}$ の濃度である.

重量平均重合度 $\left(P_{\mathrm{w}}\right)$ は, 次式によって算出した。

$$
P_{\mathrm{w}}=M_{\mathrm{w}} /(162.1+80.0 D S)
$$

\section{$2 \cdot 1 \cdot 3$ 固有粘度及び数平均重合度}

$\mathrm{NaCMC}$ のような高分子電解質の希薄溶液の還元粘度 $\eta_{\mathrm{sp}} / c(乙$ こで， $\eta_{\mathrm{sp}}$ は比粘度， $c$ は高分子濃度）は，非電解質高分子の溶 液と異なり，特異な挙動を示し， $\eta_{\mathrm{sp}} / c \sim c$ の測定による極限粘度 数 $[\eta] \equiv\left(\eta_{\mathrm{sp}} / c\right)_{c \rightarrow 0}$ の決定は困難である ${ }^{14), 15)}$. 乙の現象は，高分 子電解質に含まれる電離基の作用によるあので, 低分子塩の添加 によって押えられるが, 添加塩濃度の低い範囲では, $\eta_{\mathrm{sp}} / c \sim c の$ 関係に極大がみられる. しかし, 比較的高濃度の塩の添加によっ て, 非電解質高分子と同様, $\eta_{\mathrm{sp}} / c \sim c$ 曲線の $c=0$ への外挿によ り〔ク]の測定が可能になる.

試料とした $\mathrm{NaCMC}$ の[ク]は, $0.1 \mathrm{~N} \mathrm{NaCl}$ 水溶液を分散媒 として, Ubbelohde 型粘度計により測定した。 また，[ク]から数 平均重合度 $\left(P_{\mathrm{n}}\right)$ を算出するに当たっては，香川ら ${ }^{16)}$ が $2 \mathrm{~N} \mathrm{NaOH}$ を溶媒として浸透圧法による $P_{\mathrm{n}}$ 值との関係から求めた式

$[\eta]_{2 \mathrm{~N} \mathrm{NaOH}}=K_{\mathrm{m}} P_{\mathrm{n}}\left(K_{\mathrm{m}}\right.$ エーテル化度に依存する定数 $)$

をむとに, Fujita らが $\mathrm{NaCl}$ 溶液の $[\eta]$ と関係づけた式 ${ }^{14)}$

$$
[\eta]_{0.1 \mathrm{~N} \mathrm{NaCl}}=16.6 K_{\mathrm{m}} P_{\mathrm{n}}
$$

を用いた。

\section{$2 \cdot 2$ 粘弾性}

粘弾性の測定には，円錐一円板型レオメーター (Rheometric 社 製メカニカルスペクトロメーター）を用いた。円錐直径 $5 \mathrm{~cm}$, 円 錐角 $1.7 \mathrm{deg}$ で, 歪 $10 \%, 10^{-2} \sim 10^{2} \mathrm{sec}^{-1}$ の周波数範囲で, 27 , $40,60^{\circ} \mathrm{C}$ 亿扔て, 町蔵剛性率 $G^{\prime}$, 損失剛性率 $G^{\prime \prime}$ を測定し, 時 間一温度の重ね合わせを試みた。なお，歪10\%ではすべての系は 線形粘弾性を示す.

\section{3. 結果と考察}

\section{$3 \cdot 1$ 分子量亡 $[\eta]$ の関係}

$0.1 \mathrm{~N} \mathrm{NaCl}$ 水溶液を分散媒とした $\mathrm{NaCMC}$ の $\eta_{\mathrm{sp}} / c \sim c$, 及び $\left(\ln \eta_{\mathrm{r}}\right) / c \sim c$ の関係（ここで， $\eta_{\mathrm{r}}$ は相対粘度）を Fig. 1 亿示し た．両者とむ， $\mathrm{NaCMC}$ のエーテル化度 $D S$ 亿かかわらず直線 性を示す. 乙の図より $c=0$ の外挿値として，〔ク〕を求めるこ之 ができる．ただし， $D S \approx 0.5$ の CM1, CM13, CM25 は $0.1 \mathrm{~N}$ $\mathrm{NaCl}$ 水溶液に分散させた時, 透明な溶液にならず, [ク]を求め るととはできなかった。

〔ク]の値と, カドキセン溶媒を用いて光散乱法によって測定し た重量平均分子量 $\left(M_{\mathrm{w}}\right)$, 及び式(1)から求めた重量平均重合度 $\left(P_{\mathrm{w}}\right)$ との関係を, Fig. 2 (a, b) 亿示す.

$[\eta] \sim M_{\mathrm{w}},[\eta] \sim P_{\mathrm{w}}$ の関係と屯 $D S$ の值により 2 区分に分け られるが，いずれも勾配 1 の直線に近似される，すなわち，次の Staudinger の粘度式が成立する。

$$
[\eta]=K P_{\mathrm{w}}
$$

セルロースの誘導体に対しては, ほぼこの関係が成立するとい われている。 $K$ は $D S$ に依存し， 


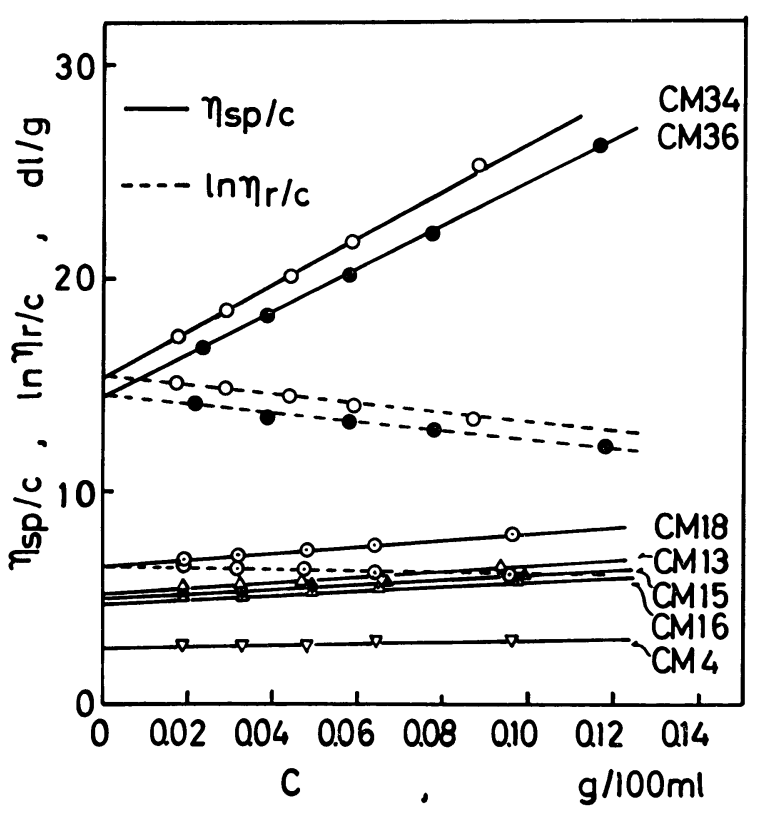

Fig. 1 Extrapolations of $\eta_{\mathrm{sp}} / c$ and $\ln \eta / c$ to zero concentration for $\mathrm{NaCMC}$ in $0.1 \mathrm{~N} \mathrm{NaCl}$ aqueous solution.
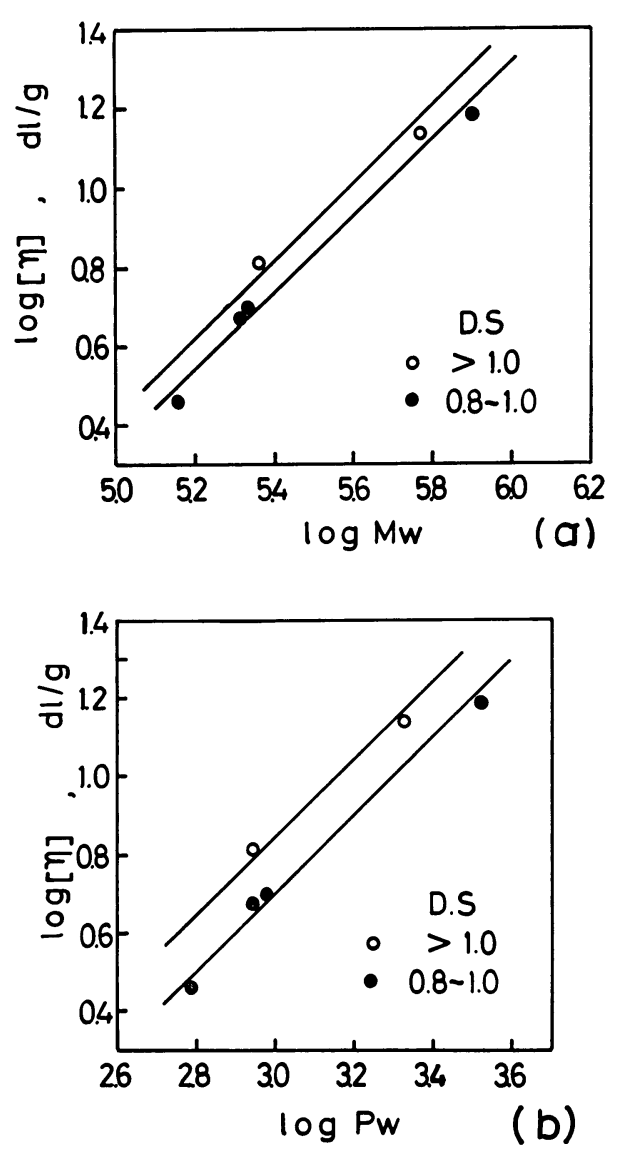

Fig. 2 Logarithmic plots of limiting viscosity number against weight average molecular weight (a) and weight average degree of polymerization (b).

$$
\begin{array}{ll}
D S=0.8 \sim 1.0 \text { 未満 } & K=5.01 \times 10^{-3} \mathrm{dl} / \mathrm{g} \\
D S=1.0 \text { 以上 } & K=6.68 \times 10^{-3} \mathrm{dl} / \mathrm{g}
\end{array}
$$

である.

$3 \cdot 2$ 粘弾性

$3 \cdot 2 \cdot 1$ エーテル化度の影響

Fig. 3 飞 CM13 $\left(D S=0.51, P_{\mathrm{w}}=922\right)$ 飞について, 高分子含 有率 $15 \mathrm{wt} \%$ 分散系の $27 \sim 60^{\circ} \mathrm{C}$ における $G^{\prime}, G^{\prime \prime}$ の周波数依存性 を示す. 低エーテル化物 CM13 の動的剛性率は, 測定周波数の 範囲では周波数依存性は小さく, また測定温度範囲では, 温度依 存性屯比較的小さい. 各温度の曲線は周波数軸に沿って水平移動 するととによって，一本の合成曲線に重ね合わせることが出来る．

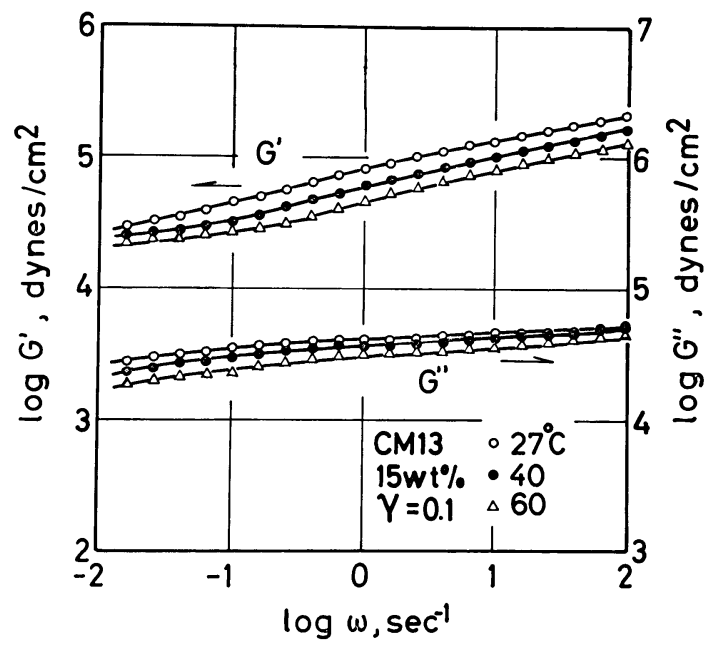

Fig. 3 Frequency dependence curves of storage and loss moduli for $15 \mathrm{wt} \%$ aqueous disperse system of CM13.
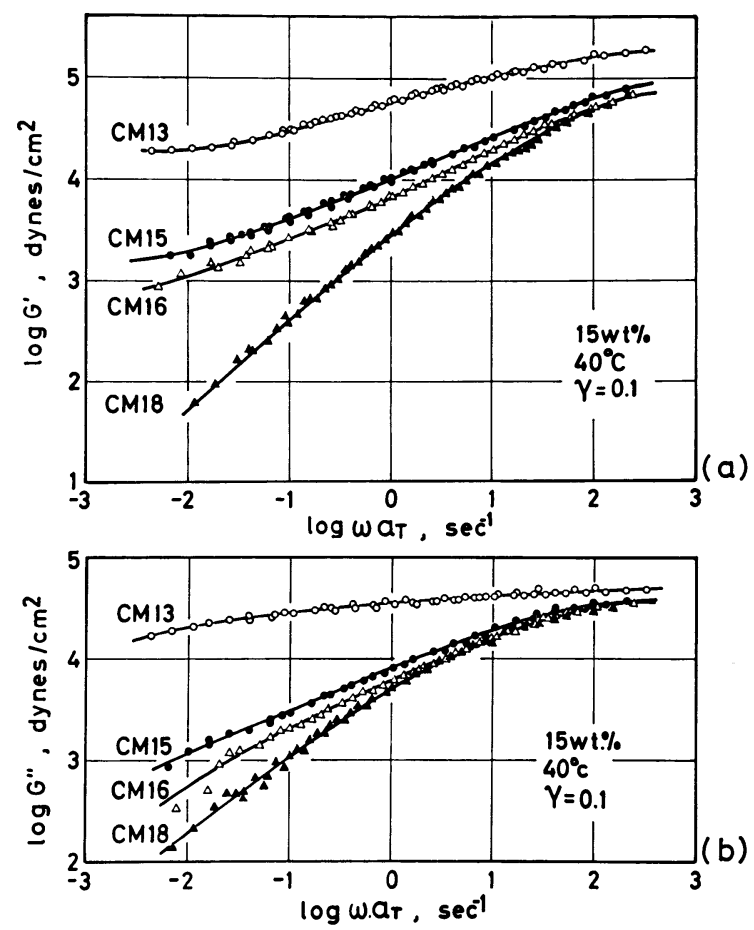

Fig. 4 Storage modulus (a) and loss modulus (b) plotted against frequency for four $\mathrm{NaCMC}$ aqueous disperse systems. 
すなわち，時間一温度の重ね合わせが成立する，他の試料すべて においても, 時間-温度の重ね合わせは成立するので, 後は $40^{\circ} \mathrm{C}$ を基準温度とした合成曲線を用いて議論を進める。

Fig. $4(\mathrm{a}, \mathrm{b})$ 亿重合度 $\left(P_{\mathrm{w}}\right)$ が殆ど同じ (880〜951) で，エ 一テル化度がそれぞれ異なる 4 種類の $\mathrm{NaCMC}$ の $15 \mathrm{wt} \%$ 分散 系の $G^{\prime}$ 及び $G^{\prime \prime}$ の周波数依存性を示す. エーテル化度が低下す るにつれて， $G^{\prime}, G^{\prime \prime}$ と屯に高くなる．乙の傾向は特に長時間側で 著しい，すなわち，エーテル化度の最む大きい CM18 の分散系の $G^{\prime}, G^{\prime \prime}$ はほぼ無定形高分子溶液と同様, 高周波数側で平坦部を示 し，低周波数側で流動領域を示す.しかし，エーテル化度の低下 につれて，低周波数側で $G^{\prime}, G^{\prime \prime}$ とあ平坦になる傾向がある。い わゆる第二平坦部を示すようになる。乙れは固体粒子分散系をは じめ不均質系に特有な挙動である.

Na-カルボキシメチル基は水中で次のように解離する.

$$
-\mathrm{OCH}_{2} \mathrm{COONa} \longrightarrow-\mathrm{OCH}_{2} \mathrm{COO}^{-}+\mathrm{Na}^{+}
$$

乙の解離基が水親和性を示し, 水中での $\mathrm{NaCMC}$ 分子の分散性 を向上させる. すなわち，グルコース残基当たりの解離基の数を 表す $D S$ 值の高い試料ほど分子分散性が良くなる傾向にあり, 分 子が動き易くなってくる. 従って, エーテル化度の影響は, 分子 全体の動きに関係する長時間側での挙動に特に著しく現われると 考えられる。

Fig. 5 は, Fig. 4 亿示した系の直交偏光子下における偏光顕 微鏡写真である.いずれの系であセルロースの未反応物が一部残 存しているが, $D S$ の大きい CM18 では, その残存量はわずか で，ほぼ等方性液体になっている，DS の低下とともに残存量は

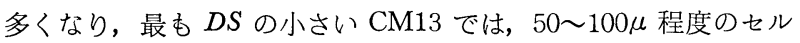
ロース結晶粒子の分散系とみなせる。乙れが CM13 分散系が固体 粒子分散系に近い性質を示している一因と考えられる。ただし， 肉眼での観察では, CM13 の場合, 分散濃度が高くなっても系は ほぼ透明であり，比較のために別途CM18 にセルロース粉末を分 散した系では，セルロース含有率が $1 \%$ む白く濁り，不透明で あった.

このととは，DS が低い試料であ全く未反応のセルロース固体

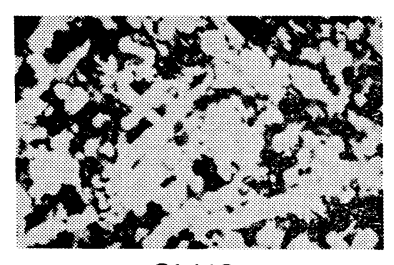
$\mathrm{CM} 13$

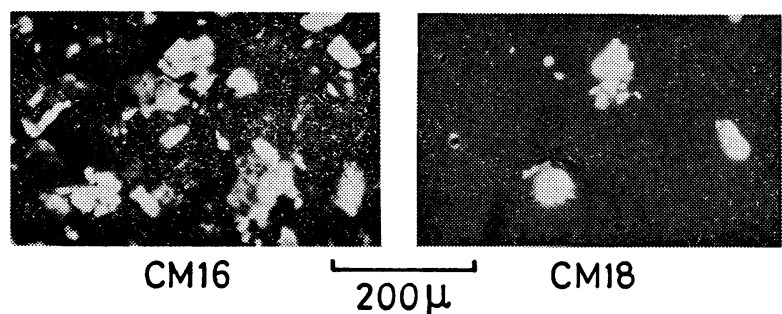

Fig. 5 Photomicrographs under crossed polarizer for four $\mathrm{NaCMC}$ aqueous disperse systems. Polymer concentration is $15 \mathrm{wt} \%$.
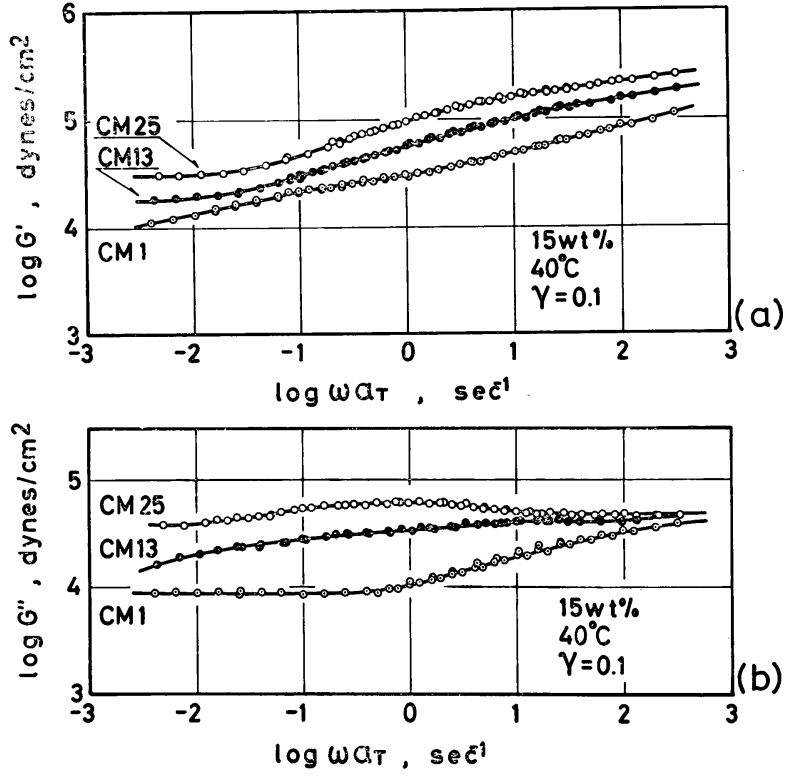

Fig. 6 Storage modulus (a) and loss modulus (b) plotted against frequency for three $\mathrm{NaCMC}$ aqueous disperse systems. These polymers have about the same $D S(\sim 0.5)$ but different $P_{\mathrm{w}}$.
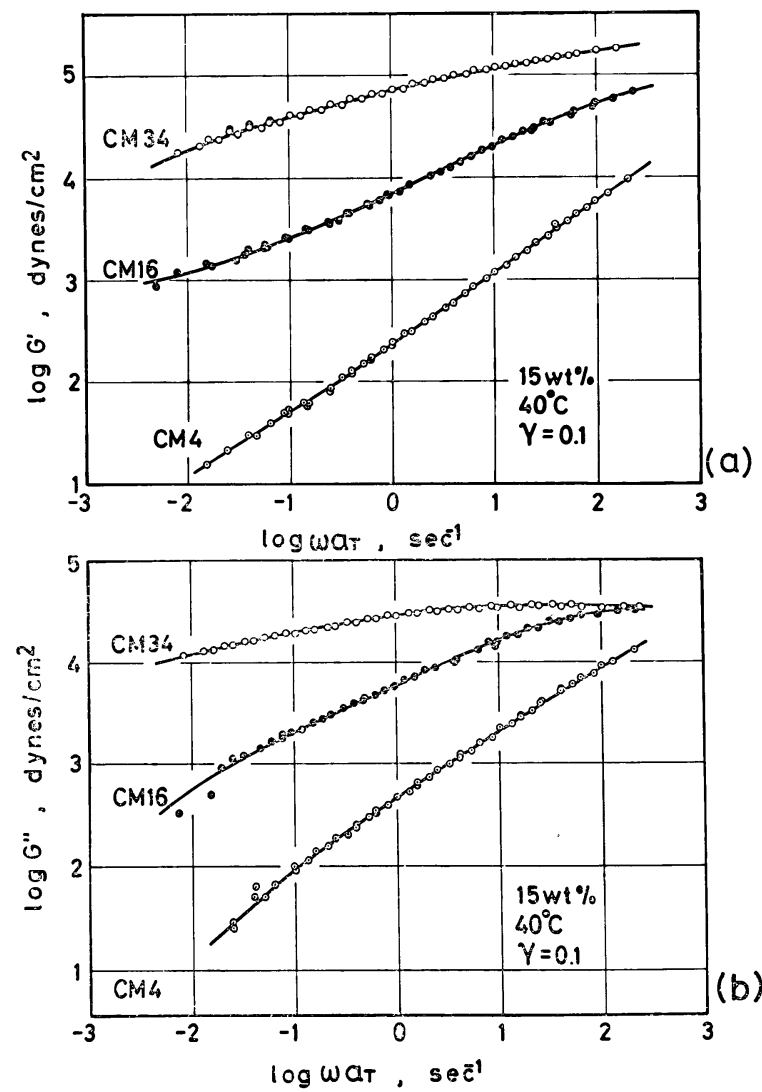

Fig. 7 Storage modulus (a) and loss modulus (b) plotted against frequency for three $\mathrm{NaCMC}$ aqueous disperse systems. These polymers have about the same $D S(\sim 0.9)$ but different $P_{\mathrm{w}}$. 
が存在しているのではなく, 反応は不均一であセルロース結晶の 周囲はエーテル化反応に関与し，均質溶液相とセルロース結晶を 結びつける役を果たしているあのと考えられる．乙の点が $G^{\prime}, G^{\prime \prime}$ における CM13 の短時間側の平坦部が，他の試料より高くなる原 因であろう.

一方, CM13 を除いた他の三つの試料における短時間側の平坦 部の高さが同じであることは，乙の平坦部が主に $\mathrm{NaCMC}$-水分 散系の均質部分, すなわち分子分散している部分のからみ合いに 依存するいわゆるゴム状平坦部に相当するととを意味する.

\section{$\mathbf{3} \cdot \mathbf{2} \cdot \mathbf{3}$ 重合度の影響}

エーテル化度はほぼ同じで, 重合度の異なる試料の $G^{\prime}, G^{\prime \prime}$ の 周波数依存性曲線を Fig. 6 (a, b), Fig. 7 (a, b) 飞示す. Fig. 6 には低エーテル化物 $(D S=0.5 \sim 0.57), \mathrm{Fg} .7$ には中程度のエ 一テル化物 $(D S=0.88 \sim 0.92)$ のデータを示す.

$P_{\mathrm{w}}$ が高くなるに従って， $G^{\prime}, G^{\prime \prime}$ と屯高くなっていくが，低エ 一テル化物では剛性率の周波数依存性は小さく, $P_{\mathrm{w}}$ の低い CM1 であ低周波数側での流動を起こさない，乙れに対し，中程度エー テル化物においては $G^{\prime}, G^{\prime \prime}$ の周波数依存性は重合度に大きく左 右され, 高重合物では比較的平坦であり, 低重合物では流れやす い性質を示している.

前述したように, 水との親和性, 分子の分散性の指標を示す $D S$ が $0.5 \sim 0.57$ と非常に低い試料は，低 $P_{\mathrm{w}}$ の試料であ分子 分散性がそれほど改善されずに，依然として分子としての動きに 制限が加えられているため, 長時間側であ不均質系特有の挙動を 示しているとみなせる. ての点は, Fig. 8 に示す偏光顕微鏡写真 からあ分かるように，低い $P_{\mathrm{w}}$ である $\mathrm{CM} 1$ であ未反応物質が依 然として多数存在していることによって推定される.

これに対し, 中程度の $D S$ の試料は, 分子分散性が完全といえ ないまでも，かなりよいため，長時間側の挙動に関与する分子個 々の性質がより顕著になる。すなわち，長い鎖は動きにくく，短 い鎖は動きやすく流れやすい, という $P_{\mathrm{w}}$ の効果が明確になって くるあのと考えられる。 なお, 低エーテル化度, 高重合度の試料 である CM25 では， $G^{\prime \prime 〜 \omega ~} \omega$ 曲線は幅広いピークを示し， $\omega=1 〜$ 0.1 付近に特異な緩和機構が現われている. てれは後述する濃度

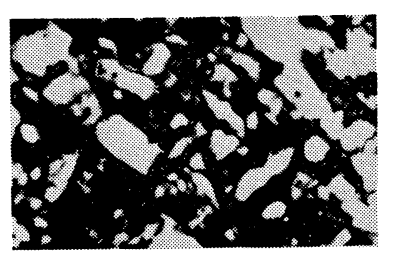

$\mathrm{CM} 1$

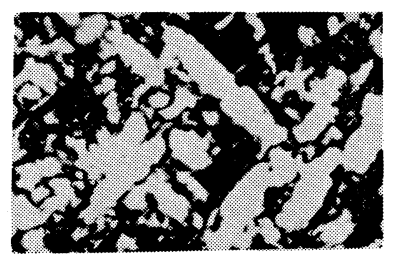

CM25

Fig. 8 Photomicrographs under crossed polarizer. Polymer content is 15 wt $\%$.
の効果の検討と併わせて, 興味ある現象である.

\section{$3 \cdot 2 \cdot 4$ 濃度の影響}

エーテル化度の異なる 3 種類の試料, CM13, CM34 及び CM18 について，いくつかの濃度における $G^{\prime}$ 及び $G^{\prime \prime}$ の周波数依存性
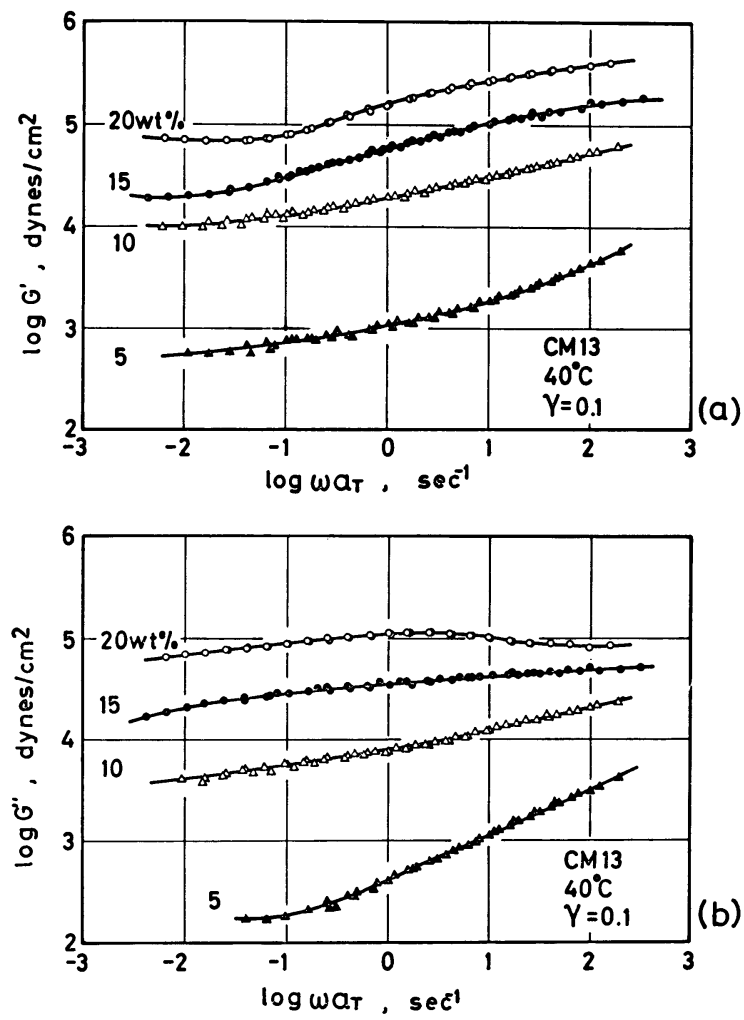

Fig. 9 Logarithmic plots of $G^{\prime}$ and $G^{\prime \prime}$ against frequency in various contents of CM13.
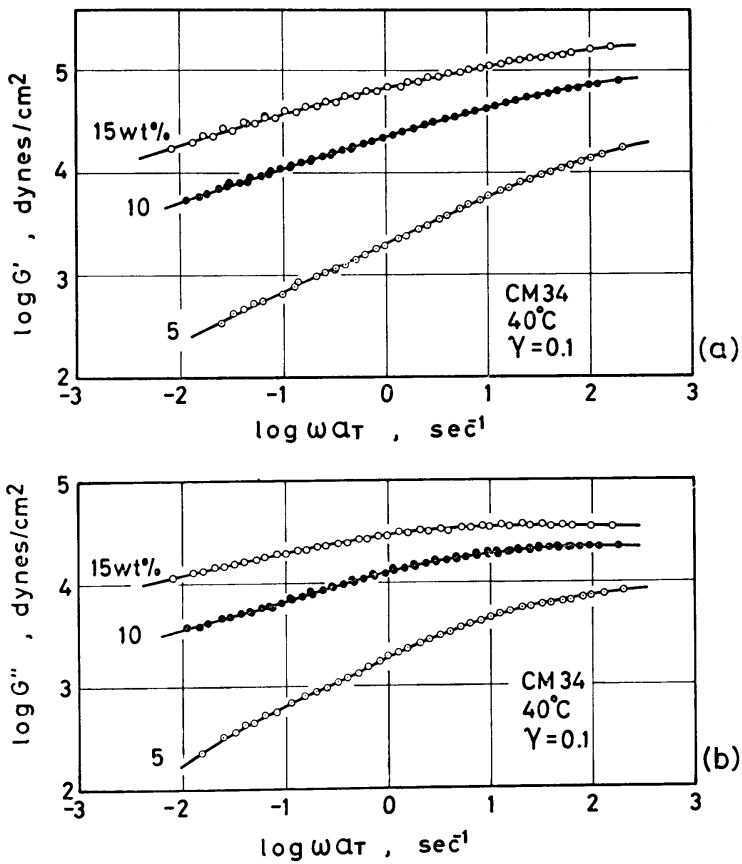

Fig. 10 Logarithmic plots of $G^{\prime}$ and $G^{\prime \prime}$ against frequency in various contents of $\mathrm{CM} 34$. 

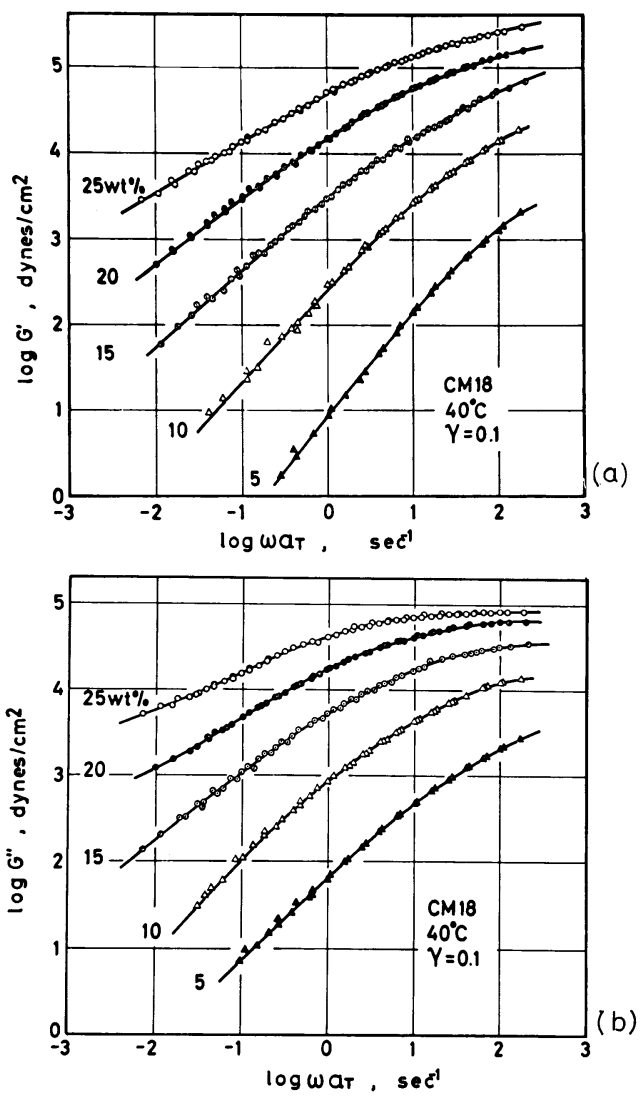

Fig. 11 Logarithmic plots of $G^{\prime}$ and $G^{\prime \prime}$ against frequency in various contents of CM18.

曲線を Fig. 9〜11 亿示した.

低エーテル化物 CM13（Fig. 9) の場合，高分子濃度 $5 \mathrm{wt} \%$ であ粘弾性曲線は不均質系の特徴を示し, 依然として流れにくい ことがわかる。

一方, Fig. 10 に示す CM34 について, CM34 が CM13 より はるかに高分子量であるにあかかわらず，DS が比較的高いため， 低濃度でやや流れやすく，低周波数側の第二平坦部屯不明瞭であ る.

高エーテル化物である CM18 (Fig. 11) では，一般の高分子液 体の粘弾性関数のゴム状平坦部から流動領域におけると同様の周 波数依存性を示し，比較的流れやすいことが分かる.

これら三つの試料を比較すると，いずれの試料とも濃度の変化 による曲線の形の変化は少ない，すなわち，すべての試料とも濃 度変化尤粘弾性の変化は, $G^{\prime}, G^{\prime \prime}$ ともに值のレベルは変えて 屯曲線の傾向, 形は殆ど変えない，乙のことはこれらの $\mathrm{NaCMC}$ では測定濃度範囲で, 濃度差による溶解度の変化等に起因する分
子内及び分子間の粘弾性機構の変化が殆どないてとを示している. さらに, CM13 の 20 wt\% の $G^{\prime \prime}$ において, $\omega=1 \sim 0.1 \mathrm{sec}^{-1}$ で幅広いピークを示し, 何らかの緩和機構の存在を示すのに対し, CM18 では 25 wt\% でもこの存在が認められない.この現象は， 前出の CM25 の $15 \mathrm{wt} \%$ の場合, 及び CM34 の $15 \mathrm{wt} \%$ に おけるかすかな変化と比べ合わせると興味深い. すなわち, 分子 の動きを規制する性質が強い方に行くほど，すなわち低エーテル 化度, 高重合度になるほど, 乙の緩和は低濃度側に現われる。乙 の緩和機構の原因については不明であるが, CM18の 15 wt\% 水 分散系にパルプ粉を20〜30\%分散させた系では, この緩和が観察 されないてとから判断するなら，一つの可能性として，七ルロー 又結晶粒子と均質溶液部分の中間相, あるいはそれらの界面にお ける分子運動をあげることができる.

以上, $\mathrm{NaCMC}$ の水分散系のレオロジー特性に関して, 電離基 密度であるエーテル化度が非常に重要な要因であるのが分ったが， このととは試料の本来の電離基密度だけでなく, 外部から電離の 程度を左右する添加イオンの種類, 濃度によっても系のレオロジ 一特性が影響を受けることを示唆している.

\section{文献}

1）黑岩城雄, 中村亦夫, 工化誌， 67, 1624 (1964).

2）黑岩城雄, 中村亦夫, 高分子化学, 22 (237), 9 (1965).

3）黒岩城夫, 中村亦夫, 高分子化学, 22 (243), 395 (1965).

4) 甘利武司, 中村亦夫, 工化誌, 73, 781 (1970).

5) Riande, E., and J.M. Pereña, Die Makromol., 175, 2923 (1974).

6) Elliot, J.H., and A.J. Ganz, Rheol. Acta, 13, 670 (1974).

7）国府田悦男, 平田光男, 岩井信次, 高分子論文集, $\mathbf{3 2}$, 235 (1975).

8）代田忠, 平佐興彦, 工業技術院繊維工業試験所報告, 60 , 57 (1962).

9）渡辺鋼市郎，中村亦夫，工化誌， 69, 1983 (1966).

10) Kuroiwa, S., M. Ogawa, and M. Nakamura, Bull. Chem. Soc., Japan, 40, 2195 (1967).

11）食品添加物公定書.

12）平佐興彦, 代田忠, 中島富士雄, 工業技術院繊維工業試験 所報告, 71、43 (1965).

13) Brown, W., D. Henley, and J. Öhman, Makromol, 62, 164 (1963).

14) Fujita, H., and T. Homma, J. Polym. Sci., 15, 277 (1955).

15) Terayama, H., and F.T. Wall, J. Polym. Sci., 16, 357 (1955).

16）香川毓美, 福田 守, 工化誌, 54, 97 (1951). 